\title{
Variation in Virulence in Xanthomonas oryzae pv. oryzae Isolates Collected from South India
}

\author{
Rahul R. Bakade ${ }^{1^{*}}$ and M. K. Prasanna Kumar ${ }^{2}$ \\ ${ }^{1}$ ICAR-Indian Institute of Natural Resins and Gum, ${ }^{2}$ Department of Plant Pathology, College \\ of Agriculture, UAS, GKVK Bengaluru, India \\ *Corresponding author
}

\begin{abstract}
A B S T R A C T
\end{abstract}
\section{Keywords}

Xanthomonas oryzae, Bacterial leaf blight

Article Info

Accepted:

07 November 2020

Available Online:

10 December 2020
Bacterial leaf blight on rice caused by Xanthomonas oryzae pv. oryzae (Xoo) is one most destructive disease on rice. The disease severity of this bacteria differs from geographical regions, strain (race) and the host genotype. Southern India grows rice and the disease incidence is very frequent as the climatic conditions are congenial for infections. However, the disease severity differs from place to place and efforts have made to understand the virulence efficiency of different isolates of Xoo from different locations of south India. All the isolates were successfully cultured in the laboratory and were confirmed by $16 \mathrm{~S} r R \mathrm{~A}$ sequencing. The sequence homology among the strains was similar except Xoo7 and has 99-100\% homology with Xoo strain PXO99A. Based on nearest neighbor analysis first group of isolates are close to PXO61, OS198 and PXO 364 isolates from outside India. Second group with only Xoo7 is close to PXO513. Further the amounts of exopolysaccharide (EPS) produced were quantified that varied depending on Xoo isolates. The EPS were produced more by isolate Xoo5 followed by Xoo4, Xoo7 and Xoo10 and the least was in Xoo3. The pathogenicity assay among the Xoo isolate showed that all isolates were virulent and amongst them Xoo3 showed least necrotic lesions with less bacterial count (in planta). Further the presence of many effectors were confirmed by PCR analysis in all isolates, however the two Non-TAL effector genes XopP and XopV were not detected in any isolates. This study demonstrates that diversity in the Xoo infection exists among south Indian isolates and further the infection process of different isolates based on geographical region needs to be studied individually to develop resistance strategies against Xoo.

\section{Introduction}

Rice, one of the most important food crop, is constantly challenged by bacterial pathogens, such as those causing bacterial blight, leaf streak, and bacterial panicle blight. Bacterial blight (BB), caused by Xanthomonas oryzae pv. oryzae, is a prevalent and destructive rice disease, particularly in tropical Asia (Mew et al., 1993) that causes annual yield losses ranging from 10 to $20 \%$ and up to $50 \%$ to $70 \%$ in severely infected fields (Mew et al., 1987).

In India, the first report of BLB was made by Bhapkar et al., 1960 and it is one of the most 
devastating diseases during monsoon season and a major production constraint in rice cultivation particularly in irrigated and rainfed lowland ecosystems of rice growing states of India10. BLB is a major problem in Kharif season crop in rice growing regions of Punjab, Haryana, Uttaranchal, Bihar, West Bengal, Tripura, Assam, Tamil Nadu, Karnataka, coastal areas of Andhra Pradesh, Eastern Uttar Pradesh and Andaman and Nicobar Islands, Kerala, parts of Maharashtra, Chhattisgarh, Gujarat and Himachal Pradesh.

$\mathrm{BB}$ is characterized by high degree of racecultivar specificity. Pathogenicity of Xoo races is different toward rice cultivars and major race of Xoo may also be different both in geographic regions and time periods. Hence, Xoo is a rapid evolving pathogen (Salzberg et al., 2008). The selection of cultivated rice varieties may facilitate the race shift or result in the emergence of new races. Indeed, a prior study showed that the shifting of the major race over time in the Philippines might be caused by a dramatic change in the host genotypes (Quibod et al., 2016). The population dynamics of Xoo were monitored in resistant and susceptible rice cultivars, bacterial populations in both the compatible and incompatible interactions increased almost equally in the initial stage of infection. Thereafter, however, the virulent population multiplied more rapidly and extensively than that of the avirulent ones (Noda et al., 1999).

Although over 46 resistance genes have been genetically defined in rice cultivars and germplasm, the effectiveness of resistance genes varies across locations due to the geographical structure of the pathogen population (Chen et al., 2020). The evolution of new pathogenic races remains a constant potential threat, as indicated by the case of breakdown of resistance in the Japanese cultivar Asakaze in 1957. To prevent such breakdown of resistance, several breeding strategies have been proposed, the success of which depends on careful race prediction of pathogens and detailed genetic information on the resistance of rice cultivars.

Xoo produces a different virulence factors, including, extracellular enzymes, type III effectors and EPS (Liu et al., 2014). During initial stages of plant pathogen interactions and disease development exopolysaccharide (EPS) helps in facilitating adhesion of bacteria to the host surface (Subramoni et al., 2006). Loss of EPS production has been correlated with loss of virulence in plant pathogens (Coplin and Cook, 1990). Role of EPS in virulence of $X$. oryzae pv. oryzae has been established by a transposon insertion in the gumG homologue of the mutant strain, BXO1002 (Dharmapuri and Sonti, 1999). Generally Xanthomonads require a type III secretion system (T3SS) for pathogenicity on plant hosts and the requirement reflects the utilization of T3 effectors to mediate the processes of pathogen adaptation to specific host tissues, species and cultivars by delivering effector proteins into the plant cell (Buttner and He 2009; White et al., 2009; Verdier et al., 2012). The effectors are grouped on the basis of sequence relatedness. The candidate status of an effector is based on the lack of functional secretion and/or translocation. Hence, the diversity in pathogenicity makes the pathogen more strong to overcome the diverse genotypes and by comparing Xoo populations in neighboring regions, it would be possible to delineate the relationships among them which further help to focus on the fast-evolving pathogenicityrelated genes for breeding of the blightresistant rice.

The emphasis of the study is to understand the virulence mechanisms of different isolate of Xoo based on different geographical regions of southern India. This study aimed to characterize virulence factors of nine Xoo 
isolates. The study provided new insights for the development of effective disease control methods that can be used based on geographical locations.

\section{Materials and Methods}

\section{Collection of $\mathrm{Xoo}$ isolates and culturing in the lab conditions and pathogenicity}

The collection of symptomatic leaf samples of bacterial leaf blight of rice from Davangiri, Chikkamangalur, Gangavathi, Bidar, Shivamogga, Coimbatore (Tamil Nadu) and Hyderabad (Andra Pradesh) has been done. Pathogen was isolated in lab and nine different $X o o$ isolates were characterized.

\section{Confirmation of pathogen using 16S rRNA}

The DNA extraction was performed according to Zhang et al., (1998) with some modification. Totally $0.3 \mathrm{~g}$ of washed bacterial cell was suspended in $200 \mu \mathrm{l}$ of Cetyl trimethylammonium bromide (CTAB) buffer (50 mM Tris, pH 8.0; $0.7 \mathrm{mM} \mathrm{NaCl}$; $10 \mathrm{mM}$ EDTA; 2\% hexadecyltrimethylammonium bromide, followed by $100 \mu \mathrm{l}$ of $10 \%$ sodium dodecyl sulfate, and incubated at $65^{\circ} \mathrm{C}$ for $20 \mathrm{~min}$. DNA was purified by two extractions with chloroform and precipitated with iso-propanol at $-20^{\circ} \mathrm{C}$. Purified DNA was washed with $70 \%$ ethanol, then was dried and resuspended in $200 \mu \mathrm{l}$ of sterile distilled water. DNA concentration was measured using a spectrophotometer at $260 \mathrm{~nm}$. DNA quality was checked on a $1 \%$ agarose gel in Tris-Acetate-EDTA (TAE) buffer (45 mM Tris-acetate, 1 mM EDTA, $\mathrm{pH}$ 8.0) after electrophoresis.

To amplify the full length of bacterial $16 \mathrm{~s}$ rDNA the primers $F$ (5'- GAGTTTGATCC TGGCTCAG -3' and R (5'- AGAAAGGAG GTGATCCAGCC-3') were used (Chao et al., 2008). Each $20 \mu \mathrm{l}$ PCR mixture contained $2 \mu \mathrm{l}$ of taq polymerase buffer, $200 \mu \mathrm{M}$ of each dNTP, 500nM of each primer, $1 \mathrm{U}$ of Taq polymerase, and $10 \mathrm{ng}$ of the DNA template. The PCR conditions were $96{ }^{\circ} \mathrm{C}$ for $5 \mathrm{~min} ; 30$ cycles consisting of $96{ }^{\circ} \mathrm{C}$ for $1 \mathrm{~min}, 58{ }^{\circ} \mathrm{C}$ for $1.5 \mathrm{~min}$, and $72{ }^{\circ} \mathrm{C}$ for $1 \mathrm{~min}$; and $72{ }^{\circ} \mathrm{C}$ for $7 \mathrm{~min}$. The PCR products were subjected to gel electrophoresis in $1 \%$ agarose gel, followed by ethidium bromide staining. The PCR product was sequenced (Agrigenome). Sequence assembly was performed with Bio Edit software. Similarity searches with sequences were performed by online BLAST analysis. For phylogenetic analysis, sequences were aligned by using the ClustalW software.

\section{Measurement of Exopolysaccharide (EPS)}

The measurement of exopolysaccharide (EPS) was conducted as described by Jeong et al., (2008). A single colony of each Xoo isolate was inoculated in $40 \mathrm{ml}$ of nutrient broth medium and incubated for $72 \mathrm{~h}$ at $28^{\circ} \mathrm{C}$ with agitation. The optical density of the bacterial cultures was adjusted to 1.0 at $600 \mathrm{~nm}$ with NB.

The culture supernatants were transferred into new 50-ml tubes and supplemented with $1.0 \%$ potassium chloride (w/v; final concentration). Two volumes of absolute ethanol were added to each solution, and the tubes were placed at $-20^{\circ} \mathrm{C}$ overnight. The precipitated crude EPS was collected by centrifugation for $30 \mathrm{~min}$ at $83,000 \times \mathrm{g}$. The EPS pellets were dried at $55^{\circ} \mathrm{C}$ for $12 \mathrm{~h}$ and the dry weight of each was measured.

\section{Growth curve determination}

Xoo isolates were cultured in NB for about 18 $\mathrm{h}$ to the middle logarithmic phase. Xoo cells were then harvested, and finally adjusted to OD600 $=1.0$. The resuspended Xoo culture was inoculated by $1 \%$. The absorbance at OD600 was measured at certain times, and 
the values are expressed as mean _ standard deviation. Each Xoo isolate was performed for three biological repeats.

\section{Pathogenicity and in Planta assays}

All the Xoo isolates were grown on NB medium for two days at $28{ }^{\circ} \mathrm{C}$. The bacterial cells were resuspended in MES buffer at an optical density $0.5(600 \mathrm{~nm})$. Bacterial blight inoculation was carried out on 35-40 days old plants on susceptible rice varieties TN-1 using the leaf-clipping method (Kaufmann 1973). This experiment was conducted under greenhouse conditions. For pathogenicity assay, the lesion length was measured in 6,8 , $10,12,14,16,18$ and 21 days after inoculation with 5 leaves for each isolate. In planta assay was carried out on same genotype and Xoo isolates multiplication counted at six time points after infection by leaf clipping on $2,4,6,8,10$, and 12 days after inoculation.

The in planta was assayed as described by $\mathrm{Hu}$ et al., (2007). The complete leaf was ground in autoclaved distilled water and the leaf homogenate was diluted in same. Serial dilutions were made three times and spread onto NA agar plates. The plates were incubated at $28{ }^{\circ} \mathrm{C}$ until the number of colony-forming units (cfu) per leaf was counted.

\section{Molecular confirmation of different effectors in $\mathrm{Xoo}$ isolates}

Based on earlier studies thirteen effectors genes were selected and primers were designed with help of PRIMER 3 software. This includes eight TAL effectors and five Non-TAL effectors (Table 1). For all the genes polymerase chain reaction got optimized with $20 \mu \mathrm{l}$ PCR mixture contained $2 \mu \mathrm{l}$ of taq polymerase buffer, $200 \mu \mathrm{M}$ of each dNTP, 500nM of each primer, $1 \mathrm{U}$ of Taq polymerase, and $10 \mathrm{ng}$ of the DNA template.
The PCR conditions were different for all the effector genes. The PCR products were subjected to gel electrophoresis in $1.2 \%$ agarose gel, followed by ethidium bromide staining.

\section{Results and Discussion}

\section{Identified Xoo isolates have homology with reported $X o o$ strain}

The rice Xoo infected samples from different regions was homogenized and serial dilution made and Xoo was cultured in the petriplates. Further to confirm the authenticity as the isolates are belong to Xoo family of different the genomic DNA was isolated from all the isolates and using 16s rRNA universal primers amplified an amplicon of expected $1500 \mathrm{bp}$ size in all the isolates. The 16s rRNA gene of all the Xoo isolates were sequenced and compared with the previously published 16s rRNA gene sequences of Xanthomonas oryzae pv. oryzae using the NCBI-BLAST program. The sequence identities among these 9 isolates $99-100 \%$ except Xoo7.

The result confirmed that all isolates showed high homology (99-100\%) to Xanthomonas oryzae pv. oryzae PXO99A. The ClustalW analysis of the 16S rRNA gene sequences revealed two groups. The first group includes almost all the isolate like Xoo1, Xoo2, Xoo3, Xoo4, Xoo5, Xoo6, Xoo9 and Xoo10. The second group containing only one isolate Xoo7 which is from Gangavathi area of Karnataka and totally different from all other isolates and more similar to PXO513 Xoo isolate from USA (Fig. 1). In the first group isolates Xoo4, Xoo5 and Xoo6 are similar to USA isolate PXO61 and Xoo2 is more similar to OS198 a China isolate.

\section{Variation in $\mathrm{Xoo}$ isolates growth in lab media}

To assess the bacterial growth in the laboratory conditions from different isolates, 
each isolate was cultured and bacterial growth rates were monitored for every $12 \mathrm{~h}$. The bacterial growth has been plotted as the logarithm of the number of viable cells versus the incubation time.

The density of Xoo isolates increased from 0.1 to $1.4(\mathrm{OD} 600 \mathrm{~nm})$ during $48 \mathrm{~h}$ of growth at $28^{\circ} \mathrm{C}$ (Fig. 2). Up to $12 \mathrm{~h}$ of growth the cell started the early exponential and reached its maximum at stationary phase on $24 \mathrm{~h}$ and up to $48 \mathrm{~h}$ remained stable as a stationary phase. The growth rate is highest in Xoo5 isolate on exponential phase $(12-24 \mathrm{~h})$ is higher than all other isolates and further the growth was maintained higher in stationary phase.

Variation in the production of exopolysaccharide (EPS) by Xoo isolates

The production of exopolysaccharide (EPS) is a characteristic feature of xanthomonads. To assess the EPS accumulation in different isolates biochemical assay is being carried out. Isolate xoo5 produced distinctly high amount of EPS in this study $(83.2 \mathrm{mg})$ followed by xoo4, xoo7 and Xoo10. On the contrary isolates xoo3 produced distinctly less amount of EPS. The isolates xoo1, xoo6 and xoo9 gave 35-40 mg dry weight of EPS (Fig. $3)$.

To assess the severity of disease infection by different isolates, the susceptible cultivar TN1 was challenged with Xoo. All tested isolates caused leaf blight on the surface on $6^{\text {th }}$ days after inoculation.

Symptoms of BB appeared on leaves as palegreen to grey-green water-soaked streaks near the leaf tip and margin. These lesions coalesced and became yellowish-white with wavy edges. On leaf sheath of susceptible cultivars, the affected leaves will turn yellow, roll up and wilt rapidly and systemic infection that produces tannish grey to white lesions along the vein under greenhouse inoculation (Fig. 4). Differences in virulence among the Xoo isolates were quantified according to the lesion length of the necrotic area. Xoo5, Xoo7, Xoo9, Xoo10 and Xoo4 isolates were shown to cause symptoms at day 6 after inoculation while Xoo1, Xoo2, Xoo3 and XOo6 isolates were shown symptoms on 7 DPI. It also showed the maximum development of disease and increased virulence to susceptible rice cultivar $\mathrm{TN}-1$ at $21 \mathrm{~d}$ post inoculation.

The average lesion length was $10-15 \mathrm{~cm}$ at 21 $\mathrm{d}$ post inoculation. Isolate Xoo3 showed the lowest lesion length and xoo5 was the highest lesion length at day 21 post inoculation (Fig. $5)$.

In-planta bacterial multiplication rate of Xoo isolates were zero in almost all the plant expect xoo5 at $2^{\text {nd }}$ DPI but it start increasing from 4 DPI to 12 DPI. Bacterial multiplication rate was high up to 8 DPI. In the plant inoculated with isolate Xoo5 showed maximum $\mathrm{CFU}$ from start to end and CFU count was lowest in Xoo3. In rest of the isolates the bacterial growth was almost similar (Fig. 6).

\section{Confirmation of effectors in Xoo isolates}

Virulence of Xoo isolates also relies on the effectors secreted into host cells through the highly conserved type III secretion system (T3SS). PCR is done with genomic DNA of all Xoo isolates and out of eight TAL effectors genes all are exist in the all our Xoo isolates. In case of Non-TAL effectors XopP and XopV did not foind not even in single Xoo isolate. 
Table.1 List of effector genes

\begin{tabular}{|l|l|l|l|l|l|l|l|l|l|}
\hline & Xoo1 & Xoo2 & Xoo3 & Xoo4 & Xoo5 & Xoo6 & Xoo7 & Xoo9 & Xoo10 \\
\hline Pth Xo1 & + & + & + & + & + & + & + & + & + \\
\hline Pth Xo6 & + & + & + & + & + & + & + & + & + \\
\hline Pth Xo7 & + & + & + & + & + & + & + & + & + \\
\hline Tal2a & + & + & + & + & + & + & + & + & + \\
\hline Tal3a & + & + & + & + & + & + & + & + & + \\
\hline Tal4a & + & + & + & + & + & + & + & + & + \\
\hline Tal5a & + & + & + & + & + & + & + & + & + \\
\hline AvrBs2 & + & + & + & + & + & + & + & + & + \\
\hline XopP & - & - & - & - & - & - & - & - & - \\
\hline XopR & + & + & + & + & + & + & + & + & + \\
\hline XopV & - & - & - & - & - & - & - & - & - \\
\hline XopI & + & + & + & + & + & + & + & + & + \\
\hline XopZ & + & + & + & + & + & + & + & + & + \\
\hline
\end{tabular}

Fig.1 Sequence aligmnet and phylogentic tree construction using ClustalW analysis of 16S rRNA sequence of Indian Isolates

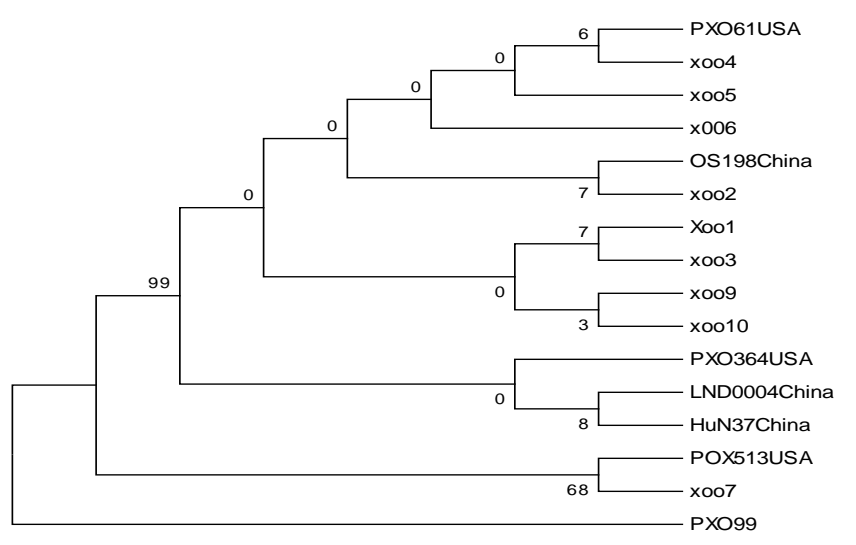

Fig.2 Optical density at $600 \mathrm{~nm}$ of nine Indian Xoo Isolates

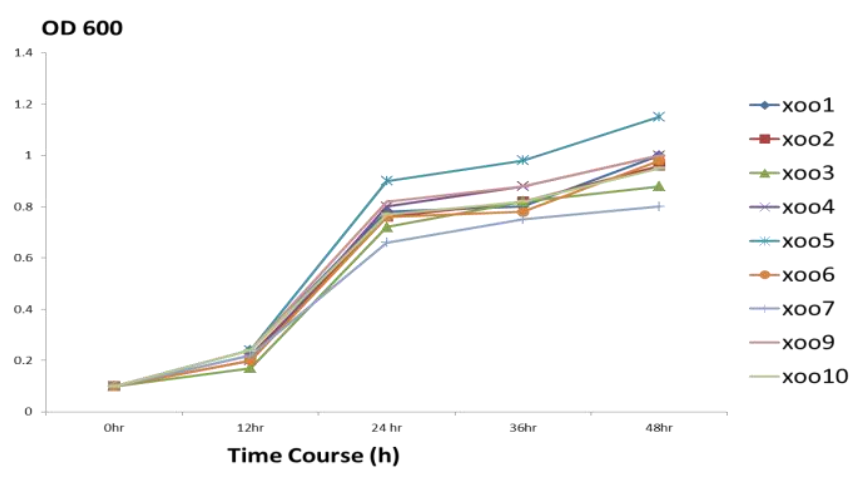


Fig.3 EPS dry weights of nine Indian Xoo Isolates

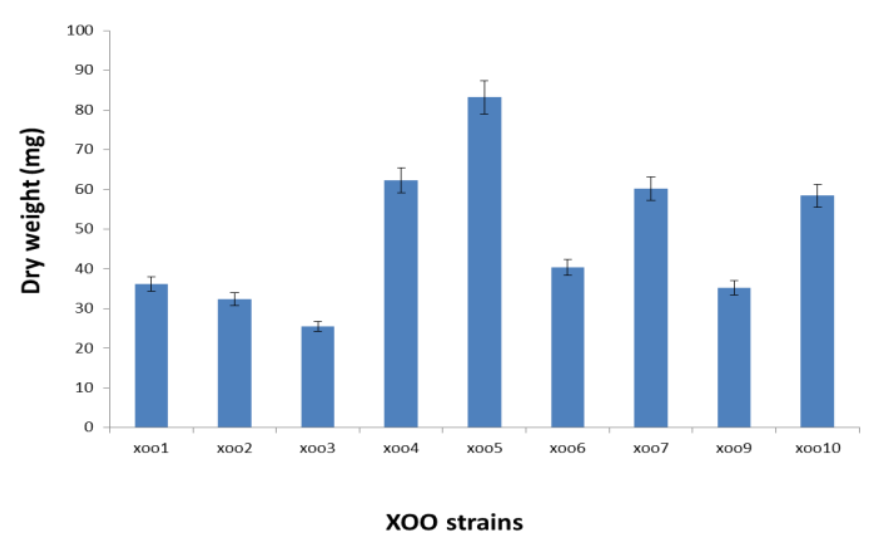

Fig.4 Leaf phenotype of TN-1 showing increased susceptibility to pathogen isolates, Lesion length count in $\mathrm{cm}$ up to $21 \mathrm{DPI}$, leaf were photographed on 21 day after inoculation

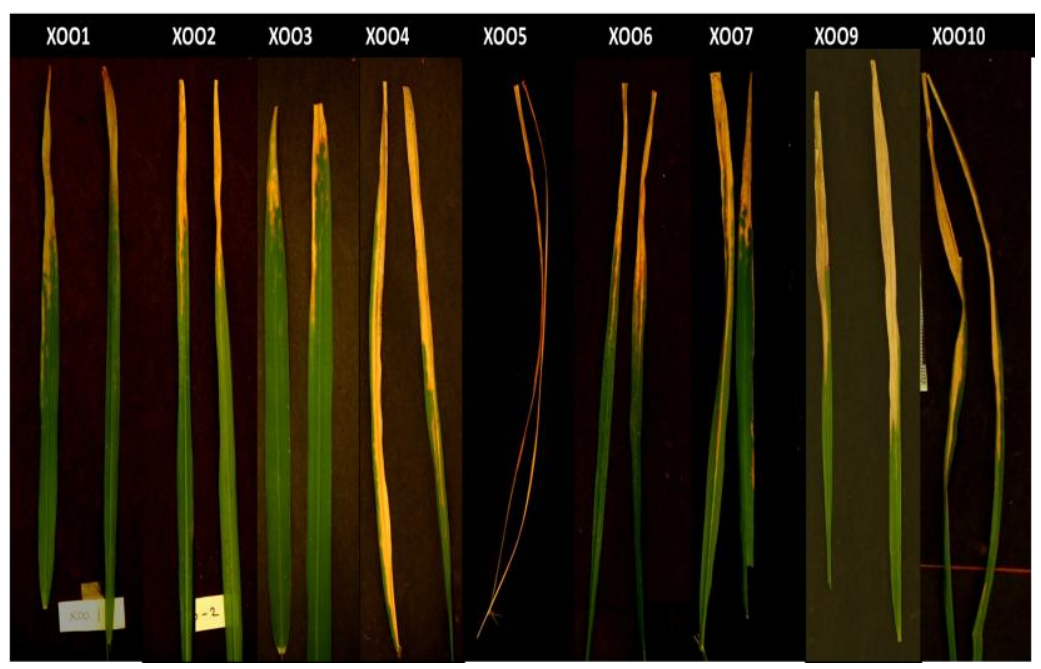

Fig.5 Lesion length of Xoo isolate were recorded from 6 days after inoculation up to 21 days

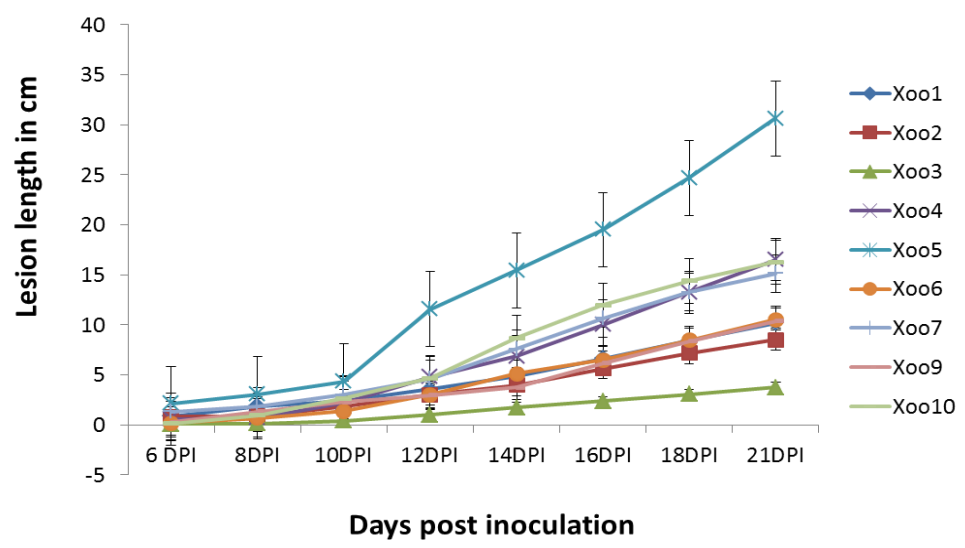


Fig.6 Bacterial multiplication rate counted from 4 days post inoculation (DPI) up to 12 DPI. The disease increase was monitored even after 12 DPI

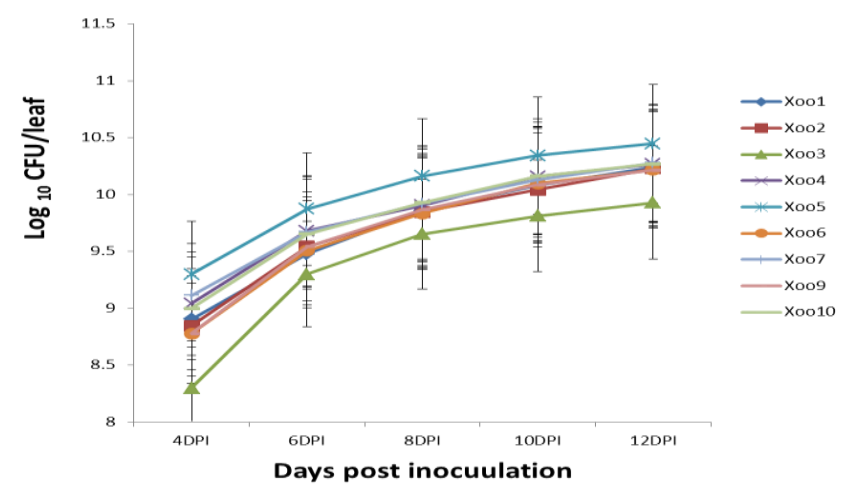

Southern India grows rice and the disease incidence is very frequent as the climatic conditions are congenial for infections. However, the disease severity differs from place to place and efforts have made to understand the virulence efficiency of different isolates of Xoo from different locations of south India. 16 rRNA gene sequence of bacterial is the most conserved and still used to confirm the identity of isolates. This sequence is most typically used for classification of bacteria. In this study, the 16S rRNA gene sequenced of all Xoo isolates used confirmed high homology to Xanthomonas oryzae pv. oryzae PXO99. Among the isolates Xoo7 is little different from other collected isolates showed similarity with USA Xoo isolate PXO513. Whereas Xoo7 and Xoo5 are collected from same place, Gangavathi, an area of Karnataka an important rice growing area of south India. Based on the homology of 16s rRNA sequencing the created phylogenetic tree depicts the relationship among the Xoo isolates. The Indian Xoo isolates was clustered as the same with PXO99 A (Salzberg et al., 2008). The high degree of diversity of Xanthomonas isolates within and between countries has been reported (Lang. et al., 2010). Hauben et al., (1997) reported that a very small degree of divergence of $16 \mathrm{~S}$
rRNA gene sequences among the Xanthomonas.

The growth rate of isolate Xoo5 was highest as well as with respect to the production of EPS. This isolate Xoo7 is from Gangavathi, where in the month of July-August humidity and temperature are high, a congenial condition for rice blight. Xoo3, an isolate from Shivamogga, which is not traditional rice producing belt, was lowest in EPS production. Thein and Prathuangwong (2010) reported that colonies of mutants were smaller when compared with the wild type that resulted from less production of EPS. The genomic analysis showed that Xanthomonas isolates possess pathogenicity and virulence factor genes encoding for the secretion systems, type III secretion effectors, exocellular enzymes, exopolysaccharide, lipopolysaccharide synthesis and adhesins. During the interactions between pathogens and host plants, the regulator proteins do not need to directly act on host cells, however, they play important roles in regulation of the virulence genes at certain spatial and temporal conditions (Büttner and Bonas, 2010). The virulence factors play an important role in successful establishment of Xoo in the host plant. EPS such as xanthan and lipopolysaccharides (LPS) produced by 
Xanthomonas genus are involved in disease development and act as a virulent factor (Wang et al., 2008). Some extracellular enzyme activities have been reported in high background at high concentrations of sucrose in the medium (He et al., 2006). In this study, isolate Xoo5 is more virulent phenotypically and produced more EPS, it reveals that more EPS production is responsible for high virulence. Partially purified EPS preparations have been found to induce rice leaf wilting. This may be due to cell membrane leakage caused by EPS (Yang and White 2004).

In planta expression of effector genes is potent method for recovering bacterial cells from live plant tissues and permit analyses of in vivo expression in plant-pathogen interactions (Mehta, 2003). It also helps in the early detection of genes involved in pathogenicity (Thwaites, 2004). The difference of population size and the increasing of multiplication related with the ability to colonize rice seedlings have associated with the virulence ability $\mathrm{Hu}$ et al., (2007). The pathogenicity assay among the $X o o$ isolate showed diverse virulence to susceptible rice cultivar $\mathrm{TN}-1$. Isolate Xoo5 and Xoo7 showed different growth of bacteria in planta eventhogh these isolates collected from same place (Gangavathi). Hence, genetic background also play key role in virulence. The increasing bacterial population was corelated to the development of necrotic part on the susceptible cultivar. The xrvA mutant GXN1280 and the xrvA overexpression isolate GXO3098 showed a significant reduction in lesion length compared to the wild-type isolate but the bacterial populations of these mutants in rice leaves were not significantly different from that of the wildtype (Feng et al., 2009). The evolutionary divergence, as a result of host selection, is a common phenomenon in plant pathogens (Brasier et al., 1987). This study helps to understood the distribution of effector genes among the south Indian isolates and the pattern is almost similar in all isolates. There is extensive variation among type III effectors to other plant pathogen (McCann et al., 2013). The virulence depends upon the activation of these effector genes which is guided by cognate effector binding elements (EBEs) in the host genome (Boch et al., 2014). However, to understand the virulence of these effector genes a time scale expression in planta after infection may provide significant leads.

In conclusion, isolate Xoo5 from gangavathi revealed high yield of EPS which is further evident by higher virulence and increasing population of Xoo that shows the aggressiveness in disease severity indiex. In contrary with Xoo3 from shivmogga revealed low yield of EPS, less virulence, and low number of population size with less aggressiveness in disease index. The screening of isolates for virulence related genes of Xoo needs further evaluation toward revealing the mechanisms of the complex and overlapped bacterial pathogenesis, especially in the early stage of infection. Although the results in this study need further verification, the results provided experimental clues for further investigation of the biological significance of effector genes in Xoo.

\section{References}

Bhapkar, D. G., Kulkarni, N. B. and Chavan, V. M. 1960. Bacterial blight of paddy. Poona Agricultural College Magazine, 51: 36-46.

Boch, J., Bonas, U. and Lahaye, T., 2014. TAL effectors-pathogen strategies and plant resistance engineering. New Phytol, 204, 823-832

Brasier, M. 1987. The dynamics of fungal speciation In Evolutionary Biology of the Fungi (eds Rayner, A. D. M., Brasier, C. M. \& Moore, D.) 231-260 
(Cambridge University Press, 1987).

Buttner, D. and Bonas, U. 2010. Regulation and secretion of Xanthomonas virulence factors. FEMS Microbiol Rev, 34, 107133.

Buttner, D. and He, S.Y. 2009. Type III protein secretion in plant pathogenic bacteria. Plant Physiol, 150:1656-1664.

Chao, S.Y., Tomii, K, Watanabe, Tsai, Y. 2008. Diversity of lactic acid bacteria in fermented brines used to make stinky tof, Int J Food Microbial, 123:134-141.

Chen, S., Wang, C., Yang, J., Chen, B., Wang, W., Su, J., Feng, A., Zeng, L., and Zhu, X. 2020. Identification of the novel bacterial blight resistance gene $X a 46(\mathrm{t})$ by mapping and expression analysis of the rice mutant H120. Scientific Reports. 10: 12642..

Coplin, D.L. and Cook, D., 1990, Molecular genetics of extra cellular polysaccharide biosynthesis in vascular phytopathogenic bacteria, Mol Plant Microbe Interact, 3:271-279.

Dharmapuri, S. and Sonti, V.R., 1999, A transposon insertion in the gum $G$ homologue of Xanthomonas oryzae pv. oryzae causes loss of extracellular polysaccharide production and virulence. FEMS Microbiol Let,t 179: $53-59$

Feng, J.X., Song, Z.Z., Duan, C.J., Zhao, S., WU, Y.Q., Wang, C.W., Dow, J.M. and Tang, J.L., 2009, The $x r v A$ gene of Xanthomonas oryzae pv. oryzae, encoding an H-NSlike protein, regulates virulence in rice. Microbiology, 155: 3033-3044.

Hauben, L., Vauterin, L., Swings, J. and Moore, E.R.B. 1997. Comparison of 16s Ribosomal DNA Sequences of all Xanthomonas Species. Int $J$ syst Bacterial, 2: 328-335.

He, Y.W., Wang, C., Zhou, L., Song, H., Dow, J.M. and Zhang, L.H. 2006. Dual signaling functions of the hybrid sensor kinase RpfC of involved Xanthomonas campestris either phosphorelay or receiver domain-protein interaction, $J$. Biol. Chem, 281:33414-33421.

$\mathrm{Hu}$, J.W., Qian and He, C. 2007. The Xanthomonas oryzae pv. oryzae eglXoB endoglucanase gene is required for virulence to rice. FEMS Microbiol Lett, 269 : 273-279.

Jeong, K.S., Lee, S.E., Han, J.W., Yang, S.U., Lee, B.M., Noh, T.H. and Cha, J.S. 2008. Virulence reduction and differing regulation of virulence genes in mutants of rpf Xanthomonas oryzae pv. oryzae. Plant Pathol. J, 24: 143-151.

Kauffman, H.E., Reddy, A.P.K., Hsieh, S.P.Y. and Merca, S.D. 1973. An improved technique for evaluating resistance of rice varieties to Xanthomonas oryzae pv. oryzae. Plant Diseases. Rep. 57: 537-541.

Kumar, A., Kumar S.R. and Sakthivel, N. 2003. Compositional difference of the exopolysaccharides produced by the virulent and virulent-deficient strains of Xanthomonas oryzae pv. oryzae, Curr Microbiol, 46: 251-255.

Lang, J.M., Hamilton, J.P., Diaz, M.G.Q., Van Sluys, M.A., Burgos, M.R.G, Vera Cruz, C.M., Buell, C.R., Tisserat, N.A., Leach, J.E., 2010. Genomics-based diagnostic marker development for Xanthomonas oryzae pv. oryzae and $X$. oryzae pv. oryzicola. Plant Disease, 94:311-319.

Liu, W., Jinling, L., Lindsay, T., jan, E.L., and Guo, L.W., 2014. Novel insights into rice innate immunity against bacterial and fungal pathogens. Annu. Rev. Phytopathol, 52:213-41.

Mccann, H. C., Rikkerink, E.H.A., Bertels, F., Fiers, M., LU, A., Rees-George, J., Andersen, M.T., Gleave, A.P., Haubold, B., Wohlers, M.W., David S. Guttman, Wang, P.W., Straub, C., Vanneste, J., Rainey, P.B. and Templeton M.D. 
2013. Genomic analysis of the Kiwifruit pathogen Pseudomonas syringae pv. actinidiae provides insight into the origins of an emergent plant disease. PLoS Pathog. 9, e1003503

Mehta, A. and Rosato, Y. 2003. A simple method for in vivo expression studies of Xanthomonas axonopodis pv. citri. Curr Microbiol, 47: 400-40.

Mew, T.W., 1987. Current status and future prospects of research on bacterial blight of rice. Anпи Rev Phytopathol, 25: 359382.

Mew T.W., Alvarez A.M., Leach, J.E. and Swings, J. 1993. Focus on bacterial blight of rice. Plant Dis, 77:5-12.

Noda, T. and Kaku, H. 1999. Growth of Xanthomonas oryzae pv. oryzae In Planta and in Guttation Fluid of Rice, Ann. Phytopathol. Soc. Jpn, 65: 9-14.

Noel, L., Thieme, F., Nennstiel, D. and Bonas, U. 2002. Two novel type IIIsecreted proteins of Xanthomonas campestris pv. vesicatoria are encoded within the hrp pathogenicity island. $J$. Bacteriol, 184, 1340- 1348.

Quibod, I. L. Quintero , A.P., Booher, N.J., Dossa, G.S., Grande, G., Szurek, B., Cruz, C.V., Bogdanove, A.J. and Oliva, R. 2016. Effector Diversification Contributes to Xanthomonas oryzae pv. oryzae Phenotypic Adaptation in a Semi-Isolated Environment. Sci Rep 6, 34137.

Salzberg, S.L., Sommer, D.D., Schatz, M.C., Phillippy, A.M., Rabinowicz, P.D., Tsuge, S., Furutani, A., Ochiai, H., Delcher, A.L., Kelley, D., Madupu, R., Puiu, D., Radune, D., Shumway, M., Trapnell, C., Aparna, G., Jha, G., Pandey, A., Patil, P.B., Ishihara, H., Meyer, D.F., Szurek, B., Verdier, V., Koebnik, R., Dow, J.M., Ryan, R.P., Hirata, H., Tsuyumu, S., Won Lee, S., Seo, Y.S., Sriariyanum, M., Ronald, P.C., Sonti, R.V., Van Sluys, M.A.,
Leach, J.E., White, F.F. and Bogdanove, A.J. 2008. Genome sequence and rapid evolution of the rice pathogen Xanthomonas oryzae pv. oryzae PXO99A. BMC Genomics, 204: 1-16.

Subramoni, S., Jha, G., Sonti, R.V., 2006. Plant-Associated Bacteria: Virulence Functions of Xanthomonads. 535- 571. Springer, The Netherlands.

Thein A. and S. Prathuangwong, 2010. Novel Strains of Xanthomonas oryzae pv. oryzae UV Mutated Induce Systemic Resistance in Rice against Bacterial Leaf Blight Disease. Kasetsart $J$ Nat Sci, 44: 1026-1043.

Thwaites, R., Spanu, P.D., Panopoulos, N.J., Stevens, C. and Mansfield, J.W. 2004. Transcriptional Regulation of Components of the Type III Secretion System and Effectors in Pseudomonas syringae pv. phaseolicola. Mol Plant Microbe Interact, 17: 1250-1258. doi:10.1094/MPMI.2004. 17.11.1250.

Verdier, V., Lindsay, R.T., Aaron, W.H., Rene, C. R., Andres, C., Clarice, L.S., adam, J.B. and Jan, E.L. 2012. Transcription activator-like (TAL) effectors targeting OsSWEET genes enhance virulence on diverse rice (Oryza sativa) varieties when expressed individually in a TAL effector-deficient strain of Xanthomonas oryzae, New Phytol, 4 :1197-207.

Wang CL, Xu A, Gao Y, Fan YL, Liang YT, Zheng C.K., Sun L.Q., Wang W.Q. and Zhao K.J. 2008. Generation and characterization of Tn5-tagged Xanthomonas oryzae pv. oryzae mutants that overcome Xa23 -mediated resistance to bacterial blight of rice. Eur J Plant Pathol, 123: 343-351.

White, F.F., Potnis, N., Jones, J.B. and Kloebnik, R. 2009. The type III effectors of Xanthomonas. Mol Plant Pathol, 10: 749-766. 
Yang, B. and White, F. 2004. Diverse members of the AvrBs3/PthA family of type III effectors are major virulence determinants in bacterial blight disease of rice. Mol Plant Microbe Interact, 17:1192-1200.

Zhang, Y., Uyemoto, J.K. and Kirkpatrick,
B.C. 1998. A small-scale procedure for extracting nucleic acids from woody plants infected with various phytopathogens for PCR assay. J. Virol. Methods, 71: 45-50.

\section{How to cite this article:}

Rahul R. Bakade and Prasanna Kumar, M. K. 2020. Variation in Virulence in Xanthomonas oryzae pv. oryzae Isolates Collected from South India Int.J.Curr.Microbiol.App.Sci. 9(12): 425-436. doi: https://doi.org/10.20546/ijcmas.2020.912.053 